
\title{
25 Research Square \\ Extracellular enzyme activities in tropical soils are driven by seasonal litter input
}

Karst Jacob Schaap ( $\nabla$ karstsch@gmail.com )

Wageningen University https://orcid.org/0000-0003-1627-9029

\section{Lucia Fuchslueger}

University of Vienna: Universitat Wien

\section{Carlos Alberto Quesada}

Instituto Nacional de Pesquisas da Amazônia: Instituto Nacional de Pesquisas da Amazonia

\section{Florian Hofhansl}

IIASA: International Institute for Applied Systems Analysis

\section{Oscar Valverde-Barrantes}

Florida International University

\section{Plinio Camargo}

CENA

Marcel R. Hoosbeek

Wageningen UR: Wageningen University \& Research

\section{Research Article}

Keywords: Tropical lowland forest, Nutrient stoichiometry, Leaf litter, Enzyme vectors, Extracellular enzymes, Soil nutrients

Posted Date: January 31st, 2022

DOI: https://doi.org/10.21203/rs.3.rs-1270964/v1

License: (c) (1) This work is licensed under a Creative Commons Attribution 4.0 International License.

Read Full License 


\section{Abstract \\ Background}

It is relatively unknown if and how seasonal fluctuations of tropical microbial activity affect soil nutrient availability. In tropical forests, nutrient economics are often considered to be centered around phosphorus, which might be a limiting factor to sustain crucial ecosystem processes, such as primary production and decomposition of organic material, thus in turn affecting microbial processes and associated nutrient dynamics of the forest ecosystem.

\section{Aims}

We investigate seasonal fluctuations in extracellular hydrolytic soil enzyme activities and soil nutrients and its relationship with precipitation and litterfall input, in a lowland tropical forest in the Central Amazon region.

\section{Methods}

We analyzed data obtained from monitoring microbial enzyme activity and nutrient dynamics in litter and soil and use stoichiometric enzyme theory and proportional vectors for assessing relative nutrient limitation throughout a year.

\section{Results}

Our results show that precipitation seasonality was driving leaf litterfall, which was subsequently synchronized with extracellular enzyme activities in soil, such that both litterfall and enzyme activities peaked during the dry season.

\section{Conclusions}

Our study indicates that soil extractable nutrient concentrations were positively related to microbial enzyme activities, which thus highlights the importance of soil microbial processes for nutrient cycling in this phosphorus limited ecosystem. Our results suggest that projected shifts in climate seasonality that result in longer and more pronounced dry seasons, might desynchronize seasonal patterns of aboveground nutrient input and belowground microbial activity, and thus leading to a decoupling of nutrient cycling in tropical forest ecosystems.

\section{Introduction}


Primary productivity in terrestrial ecosystems is usually limited by nitrogen $(N)$ or phosphorus $(P)$ (Vitousek et al. 2010). In tropical forests, plant productivity is generally considered to be limited by $P$ because of tropical soils' often highly weathered status and relatively old age (Walker and Syers 1976; Vitousek 1984; Cleveland et al. 2011; Du et al. 2020; Hou et al. 2020). Consequently, soil P is one of the strongest predictors of tropical forest productivity (Quesada et al. 2012). Microbial activity is considered a key process with a crucial role in ecosystem nutrient cycling (Cavicchioli et al. 2019). Microbes play an important role in coupled cycles of carbon (C), N, and $\mathrm{P}$ as both consumers and suppliers of available forms of nutrients, the latter of which facilitates plant production. Microbial foraging for nutrients is takes place largely through the secretion of extracellular enzymes (EE). Heterotrophic soil microbes are dependent on a supply of organic substrate from plants as their main energy (C) source (Soong et al. 2020), with $\mathrm{N}$ and $\mathrm{P}$ also playing a crucial role in sustaining microbial processes, with P-limitation as prevalent characteristic in tropical microbial communities (Camenzind et al. 2018). Vice versa, plant acquisition of $\mathrm{N}$ and $\mathrm{P}$ is dependent on the (largely microbial) $\mathrm{EE}$, which convert complex organic substrate to digestible products by breaking down larger polymers into smaller compounds which can then be readily taken up by all kinds of organisms (Skujinš and Burns 1976; Baldrian 2009; Burns et al. 2013; Luo et al. 2017).

Due to their significance, EE are often considered the rate limiting step in organic matter decomposition (Sinsabaugh and Follstad Shah 2012), and thus an important determinant of $\mathrm{C}$ and nutrient cycle potential in soil. Microbes, and plants to a lesser extent, secrete a range of EE (Skujiņš and Burns 1976; Burns 1982), but commonly studied soil hydrolytic enzymes act specifically on C, N, or P cycles (German et al. 2011). Roots and mycorrhizae are also contributing to the excretion of EE for P-acquisition (GarcíaGarrido et al. 2002; Lugli et al. 2020). Evidence on the relative contribution of root-phosphatase is unconclusive; some indicate it only constitutes a small contribution to soil phosphatase (Cabugao et al. 2021), while others maintain that the relative contribution of roots on phosphatase is more substantial in litter decomposition (Martins et al. 2021). Phosphatases are linked to the availability of $\mathrm{N}$ in soils, since enzymes are proteins requiring $C$ and $N$ for their production (Allen et al. 2020), linking different nutrient cycles. Dijkstra et al (2013) argued that priming of the microbial biomass in a P-limited system might show different dynamics than N-limited systems. In P limited systems, P might be obtained by desorption and inorganic P-acquisition over organic sources of the nutrient. In contrast, N-limited systems might lean more to acquisition of nutrients from organic sources by priming. Moreover, temporal environmental fluctuations make this process even more complex, limiting different factors at different moments in time (Condit et al. 2013).

The timing of these limitations is increasingly relevant under global change scenarios. If climate and seasonality change, the nutritional stresses on the ecosystem might increase due to a de-synchronization of previously connected fluxes of nutrients, their transformations, their uptake, and subsequent losses from the ecosystem. Over the course of a year, however, nutrients such as P proceed through different forms and levels of availability (Cusack et al. 2019; Schaap et al. 2021). Leaf litterfall has been shown to follow a seasonal pattern in some tropical forests (Sanches et al. 2008; Wu et al. 2016; Restrepo-Coupe et al. 2016), arguably leading to changes in decomposition (Wieder and Wright 1995), soil microbial 
community structure and function (Eaton et al. 2011; Buscardo et al. 2018; Pajares et al. 2018), soil nutrients (Yamashita et al. 2010), and fine root growth (Cordeiro et al. 2020). Synchronization of nutrient pulses takes place at different trophic levels and has a time lag between pulse and response (Yang et al. 2010). However, there is evidence that soil microbes react to litterfall asynchronously, preceding the litter input, indicating microbial regulation for nutrient competition in the wet tropics (Ruan et al. 2004), arguably because the temperature and humidity are less of a constraining factor to microbial nutrient cycling than in colder or drier ecosystems.

Temporal relationships among organic matter inputs, environmental conditions and EE expression are important for understanding soil nutrient dynamics. Seasonality in both nutrient uptake and mineralization might have implications for how limitations are dealt with by (micro)organisms and ultimately, how those limitations affect the forest nutrition on larger timescales. Most data of tropical soils and their nutritional balance comes from one-time surveys or single measurements, ignoring possible intra and inter-annual variation, hindering insight in the seasonal nutrient dynamics of the forest. In this study we investigate the dynamics of extracellular enzymes associated to $\mathrm{C}, \mathrm{N}$ and $\mathrm{P}$ cycles in a tropical forest soil. We treat them as a proxy for soil microbial activity and indicator for (microbial) nutrient demand. We studied the EE over the course of a seasonal cycle, to dissect effects of rainfall seasonality versus substrate inputs in the form of litterfall. We hypothesized: 1 ) the system to be $P$ limited, in our case reflected in relatively high enzymatic investments for P-acquisition 2) the enzymatic acquisition of mainly $\mathrm{C}$, but also $\mathrm{N}$ should be relatively constant, 3 ) nutrients entering the soil through litter inputs, as opposed to variation in temperature and precipitation, to be to be the main driver for the enzymatic investments for P-acquisition, 4) soil nutrient status to be of limited effect on EE, since enzymatic expression is more indicative of demand than supply, and 5) enzyme vectors (calculated according to Moorhead et al. 2016) to be indicative of changes in nutrient investments through the year.

\section{Methods}

\subsection{Site description and sampling strategy}

The study was carried out at the AmazonFACE experimental site ( $\left.2^{\circ} 35^{\prime} 40^{\prime \prime S}, 60^{\circ} 12^{\prime} 29^{\prime \prime} \mathrm{W}\right)$ in Central Amazonia (more info on https://amazonface.inpa.gov.br/), approximately $70 \mathrm{~km}$ north of Manaus, Brazil, in the "Cuieiras" experimental reserve (Estação Experimental de Silvicultura Tropical - EEST, see also Pereira et al. 2019), which is also the base for the LBA-K34 tower and several experimental observation stations. Characteristic for the area are old-growth tropical forests locally known as "Terra Firme" forests, situated on plateaus with nutrient poor and clay rich soils ( $>70 \%$ clay) classified as Geric Ferralsols (Quesada et al. 2010). Average annual rainfall is about $2,400 \mathrm{~mm}$, with a relatively drier period from June to October, while the average temperature fluctuates from $25.8^{\circ} \mathrm{C}$ in April to $27.9^{\circ} \mathrm{C}$ in September (Araújo et al. 2002).

\subsection{Sample collection and processing}


Soils were sampled from 18 sampling points. On 6 locations along a $400 \mathrm{~m}$ north-south transect (every $80 \mathrm{~m}$ ), we sampled 3 points in the east-west direction, with $10 \mathrm{~m}$ distance between the 3 sampling points. The sampling scheme was adopted to consistently sample soils close to the AmazonFACE plots (for details, see Lapola and Norby, 2014), without disturbing soil within the plots. Soils were sampled in monthly between February 2016 and January 2017, using a custom-made steel soil corer $(\varnothing 10 \mathrm{~cm})$. Soils were sampled at 0-5 $\mathrm{cm}$ and 5-15 cm depth and transported to the lab for sieving $(2 \mathrm{~mm})$, root and detritus removal and further processing. Litterfall was collected biweekly at the AmazonFACE plots. The total litter was dried, separated into leaf litter and other litter fractions and weighed $\left(\mathrm{kg} \mathrm{ha}^{-1}\right)$.

Aliquots were stored after oven drying $\left(48 \mathrm{~h}\right.$ at $\left.65^{\circ} \mathrm{C}\right)$ until further analysis, while selected measurements were performed in fresh soil within three days of sampling. Total soil P, extractable organic carbon, extractable nitrogen, and microbial biomass were analyzed every three months. Total soil $\mathrm{C}$ and $\mathrm{N}$ contents were determined monthly in composite samples of three (according to sampling location along the transect). Apart from the total $\mathrm{C}$ and $\mathrm{N}$ contents, all analyses were performed at the LTSP (Laboratório Temático de Solos e Plantas) laboratory at INPA (Instituto Nacional de Pesquisas da Amazônia) in Manaus, Brazil, nationally certified by Embrapa Soils (2016 Fertility Laboratory Quality Analysis Program, PAQLF, https://www.embrapa.br/en/solos/paqlf) and by the PIATV (Esalq/USP) inter-laboratorial program of vegetation tissue analysis (Grade A, http://piatv.com.br/).

Litterfall was collected biweekly at two of the AmazonFACE plots located along the transect (used in this study) starting in August 2015. Litter traps $(0.5 \times 0.5 \mathrm{~m}, \mathrm{n}=24)$ were installed $1 \mathrm{~m}$ above the ground, 12 traps per plot in a circular pattern. The total litter was dried, separated into leaf litter and other litter fractions, and weighed.

\subsection{Total $\mathrm{C}, \mathrm{N}$ and $\mathrm{P}$}

Total soil $\mathrm{C}$ and $\mathrm{N}$ were determined in milled dry aliquots by mass spectrometry (Finnegan Delta Plus) for elemental $\mathrm{C}$ and $\mathrm{N}$ (Carlo-Erba, 1110). Total $\mathrm{P}$ was determined in dry (unmilled) $0.5 \mathrm{~g}$ aliquots with the molybdate blue method (Murphy and Riley 1962) after acid digestion using concentrated sulphuric acid solution $\left(\mathrm{H}_{2} \mathrm{SO}_{4}, 18 \mathrm{M}\right.$ ), followed by $\mathrm{H}_{2} \mathrm{O}_{2}$ (Quesada et al. 2010; see also Schaap et al. 2021).

\subsection{Extractable $\mathrm{C}, \mathrm{N}$ and $\mathrm{P}$}

Extractable organic carbon (eoC) and extractable nitrogen $(\mathrm{eN})$ were obtained from extracts of 2 grams of fresh soil in $20 \mathrm{ml} 1 \mathrm{M} \mathrm{KCl}$ solution, shaken for one hour and subsequently filtered. The filtered extract was then analyzed in a TOC/TN analyzer (TOC-V CPH E200V/TNM-1 220V; Shimadzu, Vienna, Austria). Extractable $\mathrm{P}$ (Olsen et al. 1954) was determined from extractants of $2 \mathrm{~g}$ of soil in $20 \mathrm{ml} 0.5 \mathrm{M}$ bicarbonate solution $\left(\mathrm{NaHCO}_{3}, \mathrm{pH} 8.5\right)$, shaken for one hour and filtered. Extractant was analyzed following the photometrical Murphy-Riley molybdate blue method (712 nm) (Murphy and Riley 1962). All analyses were accompanied by two method blanks (no soil) to account for contamination or background signal, and possible lab variation was accounted for by analyzing standards during each batch of photometric extract reading. 


\subsection{Potential soil extracellular enzyme activities}

Potential extracellular enzyme activities (EEA) of three common hydrolytic enzymes relevant to $\mathrm{C}, \mathrm{N}$ and $\mathrm{P}$ cycling were assayed using a fluorescence method. We followed a lab protocol based on Marx et al. (2001) and calculations from German et al. (2011). 4-Methylumbelliferyl $\beta$-D-glucopyranoside (M3633 Sigma), 4-Methylumbelliferyl N-acetyl- $\beta$-D-glucosaminide (M2133) and 4-methylumbelliferyl phosphate disodium salt (M8168 Sigma) were used as substrates for $\beta$-glucosidase (BG), $N$-acetyl glucosaminidase (NAG) and acid phosphatase (AP), respectively. All are widely used in soil enzyme assays as they can be considered a proxy for microbial demand of $\mathrm{C}, \mathrm{N}$ and $\mathrm{P}$. 4-methylumbelliferone standards were used and substrate controls, sample controls and blanks were measured to control any background signal. All enzymes were assayed in soil slurries of $0.5 \mathrm{~g}$ of fresh soil dissolved in $50 \mathrm{ml}$ sodium acetate buffer ( $\mathrm{pH}$ 5.5) and vortexed for one minute before pipetting aliquots in a black microplate ( 96 well polystyrene, flat bottom). Standard curves were generated in the soil slurry using Methylumbelliferyl as a standard with appropriate standard curves (M1381 Sigma). In addition, we measured substrate controls, sample controls, and blanks to account for potential background signal. Microplates were incubated for 1 hour at $20^{\circ} \mathrm{C}$, whereafter fluorescence measurements were performed with an Infinite F200 Pro plate reader (Tecan Austria GMBH, Grödig, Austria), with fluorescence intensity measured from the top $\left(\lambda_{\text {excitation }}=360\right.$ and $\lambda_{\text {emission }}=440 \mathrm{~nm}$ ). Enzyme activities were calculated as $\mu \mathrm{mol} \mathrm{g} \mathrm{C} \mathrm{g} \mathrm{day}^{-1}$.

\subsection{Quantitative analyses}

Extracellular enzymatic stoichiometry (EES) and vectors were calculated according to Moorhead et al. (2016). Enzyme activity ratios and proportional activities were calculated using the natural logarithm. The enzyme and nutrient ratios for C:N, C:P and N:P were calculated in each sample as with In transformed ratios (e.g., $\ln (\mathrm{C}: \mathrm{N}), \ln (\mathrm{BG}: \mathrm{NAG})$, etc.), while proportional ratios were calculated as

$$
C: N_{\text {proportional }}=\ln \frac{B G}{B G+N A G}
$$

and

$$
C: P_{\text {proportional }}=\ln \frac{B G}{B G+A P}
$$

Vectors were calculated using both of those ratios, their length as

$$
\text { Vectorlength }=\sqrt{C: P_{\text {proportional }}^{2}+C:{N_{\text {proportional }}}^{2}}
$$

and their angle in degrees as

$$
\text { Vectorangle }=\tan ^{-1}\left(\frac{C: N_{\text {proportional }}}{C: P_{\text {proportional }}}\right)
$$


Means were calculated according to the stoichiometric mean recommended by Isles (2020) as the mean of each natural logarithm (i.e. mean $=\left(\ln \left(\right.\right.$ ratio $\left._{1}\right)+\ln \left(\right.$ ratio $\left._{2}\right)+\ldots+\ln \left(\right.$ ratio $\left.\left.\left._{n}\right)\right) / n\right)$, all values are reported \pm their standard error. Data processing and statistical tests were performed in R 4.1.2 (R Core Team 2020). Linear regression models were applied to assess relations between variables (Im function, base R). Relations between enzyme activities were performed with In transformed values.

((Figure 1))

\section{Results}

Precipitation showed a distinct drier period (at least $40 \%$ of days with $<3 \mathrm{~mm}$, Figure $1 \mathrm{~b}$ ) between July and November, during which it was also some degrees warmer, but average temperature varied little and stayed within a $24.5-27.5^{\circ} \mathrm{C}$ range (on average) during the measurement interval (Figure 1a, Supplementary figure S1a). During those drier months, the leaf litterfall peaked (Figure 2a). Annual leaf litterfall amounted to $5565 \pm 55 \mathrm{~kg} \mathrm{ha}^{-1}$ year $^{-1}$, with a distinct peak during the drier months. Leaf litterfall was not significantly correlated to the average monthly temperature (Supplementary figure S1b) but showed a negative relation with the average rainfall $\left(F_{(1 ; 9)}=18.9, P=0.002\right.$, Figure $\left.2 b\right)$ indicating clearly higher leaf litterfall when drier.

\section{((Figure 2))}

Average soil C concentration at $0-5 \mathrm{~cm}$ was $5.53 \pm 0.02 \%$, ranging from $4.19 \pm 0.09$ in January to $7.28 \pm$ $0.27 \%$ in May (Table S1). N concentration was $0.35 \pm 0.00 \%$ on average, peaking in May with $0.42 \pm$ $0.01 \%$ and reaching the lowest concentration in January with $0.29 \pm 0.00 \%$. Total $P$ averaged $156.39 \pm$ $0.69 \mu \mathrm{g} \mathrm{g}^{-1}$, ranging from $141.8 \pm 2.13 \mu \mathrm{g} \mathrm{g}^{-1}$ in August to $204.52 \pm 3.46 \mu \mathrm{g} \mathrm{g}^{-1}$ in February, with the note that the measurement frequency of total $P$ was lower than for $C$ and $N$ (Table S2). For $5-15 \mathrm{~cm}$, the average total $C, N$ and $P$ contents were $2.84 \pm 0.01 \%, 0.21 \pm 0.00 \%$, and $118.22 \pm 0.52 \mu \mathrm{g} \mathrm{g}^{-1} ; \mathrm{C}$ ranged from $2.03 \pm 0.03 \%$ (January) to $3.58 \pm 0.07 \%$ (June), $N$ ranged from $0.17 \pm 0.00 \%$ (January) to $0.26 \pm$ $0.01 \%$ (June) and $P$ ranged from $107.86 \pm 1.61 \mu^{-1}$ g (May) to $143.24 \pm 3.24 \mu^{-1} g^{-1}$ (February)(Table S1, Table S2). The eoC, eN and Olsen P in the top $5 \mathrm{~cm}$ of soil were $1034.06 \pm 6.17 \mu \mathrm{g} \mathrm{C} \mathrm{g}^{-1}$ dry soil, $101.41 \pm$ $0.34 \mu \mathrm{g} \mathrm{N} \mathrm{g}^{-1}$ dry soil and $2.08 \pm 0.01 \mu \mathrm{g} \mathrm{P} \mathrm{g}^{-1}$ dry soil. In $5-15 \mathrm{~cm} 10 \mathrm{~cm}$, those values were lower with $916.86 \pm 6.41 \mu \mathrm{g} \mathrm{g}^{-1}$ soil, $76.78 \pm 0.24 \mu \mathrm{g} \mathrm{g}^{-1}$ and $1.19 \pm 0.00 \mu \mathrm{g} \mathrm{g}^{-1}$ dry soil, respectively (Table 1 ). At both analyzed soil depths, the highest values for eoC were found in May $\left(1806.59 \pm 31.33 \mathrm{\mu g} \mathrm{g}^{-1}\right.$ and $1727.64 \pm 31.61 \mathrm{ug} \mathrm{g}^{-1}$ respectively), while the lowest values were measured in August (594.69 $\pm 5.98 \mu \mathrm{g}$ $\mathrm{g}^{-1}$ and $455.73 \pm 2.80 \mathrm{\mu g} \mathrm{g}^{-1}$ respectively). In contrast, the $\mathrm{eN}$ values were lowest in February at both depths (82.1 $\pm 1.54 \mu_{\mathrm{g} \mathrm{g}}^{-1}$ and $58.24 \pm 0.74 \mathrm{ug} \mathrm{g}^{-1}$ respectively), while reaching their highest values in August $\left(135.3 \pm 1.19 \mu \mathrm{g} \mathrm{g}^{-1}\right.$ and $95.92 \pm 0.58 \mu \mathrm{g} \mathrm{g}^{-1}$ respectively. Olsen P peaked in March at both depths, while in the top $5 \mathrm{~cm}$ the lowest concentration was found in April $\left(1.16 \pm 0.02 \mu \mathrm{g} \mathrm{g}^{-1}\right)$, and in the lower soil increment the lowest value was reached in January $\left(0.52 \pm 0.02 \mu \mathrm{g} \mathrm{g}^{-1}\right)$. 
EE activity on a dry soil basis in the top soil (0-5 cm) amounted to $1.13 \pm 0.00 \mu \mathrm{mol} \mathrm{g}^{-1}$ day $^{-1}$ for $\mathrm{BG}, 4.84$ $\pm 0.02 \mu \mathrm{mol} \mathrm{g}^{-1} \mathrm{day}^{-1}$ for NAG and $109.88 \pm 0.26 \mu \mathrm{mol} \mathrm{g}^{-1} \mathrm{day}^{-1}$ for AP, while in the $5-15 \mathrm{~cm}$ soil increment those values dropped to $0.64 \pm 0.00 \mu \mathrm{mol} \mathrm{g}^{-1}$ day $^{-1}, 1.76 \pm 0.00 \mu \mathrm{mol} \mathrm{g}^{-1}$ day $^{-1}$ and $70.34 \pm$ $0.19 \mu \mathrm{mol} \mathrm{g}^{-1}$ day $^{-1}$ respectively (Supplementary Figure S2). Consequently, EE activities as expressed per gram soil $C$ were determined to be $0.21 \pm 0.00 \mu \mathrm{mol} \mathrm{g} \mathrm{C}^{-1}$ day $^{-1}$ for BG, $0.87 \pm 0.00 \mu \mathrm{mol} \mathrm{g} \mathrm{C}^{-1}$ day $^{-1}$ for NAG and $20.21 \pm 0.04 \mu \mathrm{mol} \mathrm{g} \mathrm{C}{ }^{-1}$ day $^{-1}$ for AP, while in $5-15 \mathrm{~cm}$ those activities were $0.23 \pm 0.00,0.63 \pm$ 0.00 , and $26.26 \pm 0.08 \mu \mathrm{mol} \mathrm{g}$ soil $\mathrm{C}^{-1}$ day $^{-1}$ for BG, NAG and AP respectively (Figure 3a, c, e). The highest values for the EE activities in the top $5 \mathrm{~cm}$ were in the drier season, or just before, with $B G$ peaking in August $\left(0.34 \pm 0.02 \mu \mathrm{mol} \mathrm{g} \mathrm{C}^{-1}\right.$ day $\left.^{-1}\right)$, and NAG and AP peaking in September $\left(1.22 \pm 0.06 \mu \mathrm{mol} \mathrm{g} \mathrm{C}^{-1}\right.$ day $^{-1}$ and $44.61 \pm 0.90 \mu \mathrm{mol} \mathrm{g} \mathrm{C}^{-1}$ day $^{-1}$ respectively) while the lowest values were measured in the wetter months; in January for BG and NAG $\left(0.12 \pm 0.00 \mu \mathrm{mol} \mathrm{g} \mathrm{C}^{-1}\right.$ day $^{-1}$ and $0.20 \pm 0.01 \mu \mathrm{mol} \mathrm{g} \mathrm{C}{ }^{-1}$ day $^{-1}$ respectively), and in June for AP $\left(15.52 \pm 0.35 \mu \mathrm{mol} \mathrm{g} \mathrm{C}^{-1}\right.$ day $\left.^{-1}\right)$. This pattern was generally reflected at 5-15 cm, but BG and NAG peaked just before the drier season (in June, $0.31 \pm 0.01 \mu \mathrm{mol} \mathrm{g} \mathrm{C}^{-1}$

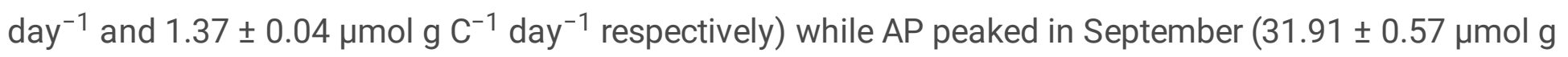
$\mathrm{C}^{-1}$ day $\left.^{-1}\right)$. The lowest EE activities at 5-15 $\mathrm{cm}$ depth were all in January (BG $0.13 \pm 0.00 \mu \mathrm{mol} \mathrm{g} \mathrm{C}{ }^{-1}$ day $^{-1}$, NAG $0.40 \pm 0.01 \mu \mathrm{mol} \mathrm{g} \mathrm{C}{ }^{-1}$ day $^{-1}$ and AP $12.80 \pm 0.19 \mu \mathrm{mol} \mathrm{g} \mathrm{C}^{-1}$ day $^{-1}$ ).

((Figure 3))

Although total nutrient contents of the soil did not seem to show a clear seasonal pattern (Table S1, S2), the EE activities were higher in the drier months from July to November. To test whether climatic factors (temperature, moisture) or leaf litter inputs to the soil were related to enzyme activities, we applied linear regression models to assess their relationship. In the top $5 \mathrm{~cm}$ the tested relation with BG proved not significant (Figure $3 b$ ), whereas the average BG activity at $5-15 \mathrm{~cm}$ was significantly related to the litterfall $\left(F_{(1,9)}=10.4, p=0.011\right.$, Figure $\left.3 b\right)$, but not to the precipitation or temperature (Supplementary Figure $S 3 a, b$ ). The NAG activity was not significantly related to any of the three examined factors (Figure 3d, Supplementary Figure S3c, d). In contrast, average AP activity was positively related to leaf litterfall in the 5-15 depth $\left(F_{(1,9)}=9.54 ; p=0.013\right)$, and a positive tendency in the top $5 \mathrm{~cm}\left(F_{(1,9)}=4.64, p=0.06\right.$; Figure $3 f)$, but negatively to precipitation $\left(F_{(1,9)}=10.57, p=0.014\right.$ for the top $5 \mathrm{~cm} ; F_{(1,9)}=9.26, p=0.01$ for 5-15 cm; Supplementary Figure S3f) at both studied soil depths.

Soil C:N and the corresponding enzyme activity ratio showed a negative relationship (for $0-5 \mathrm{~cm}: F_{(1,192)}$ $=22.59, \mathrm{p}<0.01$; for $\left.5-15 \mathrm{~cm}: \mathrm{F}_{(1,192)}=5.09, \mathrm{p}=0.03\right)$, while the $\mathrm{N}: \mathrm{P}$ ratio and corresponding $\operatorname{In}(\mathrm{NAG}: \mathrm{AP})$ showed a positive relation $\left(F_{(1,56)}=8.15, p<0.01\right.$ for the top $5 \mathrm{~cm} ; F_{(1,57)}=8.13, p<0.01$, for the $5-15 \mathrm{~cm}$ depth), C:P and associated enzyme activities (In(BG:AP)) were not significantly related (Figure 4a, C, e). Among the three tested enzymes all relations were positive and significant $(p<0.01$, Figure $4 b, d, f)$. The relation of the enzymes to the extractable $\mathrm{C}, \mathrm{N}$ and $\mathrm{P}$ were dominated by the significant relations that $\mathrm{eN}$ and the enzyme activities showed, together with the significant relations between the AP activity and the eoC, eN and Olsen P (Figure S4). 
((Figure 4))

While the EE activities showed some seasonality when considered separately (Figure 3), their activity ratios and proportional activities show less variation (Table 2). We also calculated vectors of those proportional activities, useful for distinguishing effects in relative nutrient demand. However, the vector lengths and angles of the proportional activities decrease after the drier months with higher litter inputs, indicating a shift from $\mathrm{C}$ and $\mathrm{P}$ acquisition (lower vector length) towards $\mathrm{N}$ acquisition enzymes at the start of the rain season. Moreover, the angles and the lengths of the vectors show a significant positive relationship (Figure 5, $F_{(1,191)}=6.55, p=0.01$ for the top $5 \mathrm{~cm} ; F_{(1,192)}=25, p<0.01$ for $5-15 \mathrm{~cm}$, Supplementary figure S4), indicating overall relations in relative nutrient demand; a tendency that links enzyme activities for $\mathrm{C}$ and $\mathrm{P}$ acquisition if we consider vector angle as a proxy for $\mathrm{P}$ over $\mathrm{N}$ demand and vector length as an indicator of a relative investment in $\mathrm{C}$ acquisition.

((Figure 5))

\section{Discussion}

\subsection{Overview}

In this study, we provide insight in the shifts of dynamics of nutrient limitations during the year through enzymes as a proxy for (microbial) nutrient demand. Overall, the enzyme activities point toward a strong $P$ demand; BG and NAG activities were low compared to AP. We provide evidence that the natural litter cycle is synchronized with activities of enzymes used for the acquisition of $\mathrm{P}$. This is also reflected in the enzyme vectors, which showed pre-drier season shift towards relatively more $\mathrm{N}$ acquisition, and the shift towards more P-acquisition at the end of the drier season.

\subsection{Microbial activity}

Our data shows a chronic high investment in AP, suggesting the system to be P limited as hypothesized. Phosphorus, when it has limited bioavailability in soil, must be cycled tightly, warranting both enzymatic production when available $P$ is low and strong linkage between the enzyme activities and litter inputs to the system (Schaap et al. 2021). Our EE data is in the same range as compared to enzyme activities measured along an altitude gradient in the Andes, albeit lower than on lower altitudes reported (Nottingham et al. 2016); Tischer et al. (2014) also reported similar values, although in neither study seasonality was included. In our study the soil extracellular enzyme stoichiometry and vectors were strongly influenced by the high activities of AP in the system and the relatively low values of both BG and NAG.

BG activity was low in general, and while all enzyme activities seemed to dip at the end of the drier period, the NAG activity (catalyzing the depolymerization of $C$ and N rich compounds, Luo et al. 2017) seemed to be more affected than the others. To evaluate the second hypothesis about the constant enzymatic investment in $\mathrm{C}$ and $\mathrm{N}$ acquisition by microbes, we reported activities of $\mathrm{BG}$ and NAG. Usually enzymes 
show seasonal variation (Baldrian et al. 2013; Zuccarini et al. 2020; Bai et al. 2021), but in the referred studies annual temperature variations were larger. In the current study, the microbial investment in BG and NAG is relatively small compared to AP, but there is still an observable seasonality contrary to our second hypothesis. The positive relationship between the BG activity and litter inputs in the top $5 \mathrm{~cm}$ of soil indicates a synchronization between new substrate and the investments of microbes. While substrate is available, enzymatic expression increases, possibly to fulfill microbial energy needs which could be connected to the demand for $P$.

\subsection{Leaf litter and its relation to $\mathrm{EE}$}

We hypothesized that litter inputs would be related to $\mathrm{P}$ acquisition, measured by enzyme activity. Litterfall indeed is a strong predictor of AP activity, although precipitation plays a role as well. This relation is contrasted by the lack of coupling between litter and NAG, which is illustrative of the differences between nutrient cycles and the relative limitation of the two. NAG principally catalyzes the breakdown of chitin present in for example cell walls, and a relatively higher activity could also indicate higher microbial turnover (Zeglin et al. 2013). Others also encountered difficulty relating the NAG activity to environmental factors and soil nutrients in a tropical context (Waring et al. 2014). The positive relation between BG activity in the 5-15 cm depth and the new inputs of substrate could signal an increase in microbial energetic needs while producing AP - a notion that is also supported by the pre-drier season increase in BG and NAG activities. Since temperature and precipitation were not significantly related to most enzymes and nutrients, the soil microbial activity and nutrient cycling seem to be mainly driven by inputs of substrate. In a study with differing litter input treatments in a different tropical forest (Weintraub et al. 2013), inputs were found to exert strong controls over the enzyme activities, but enzyme activities were also related to soil nutrient status.

The leaf litterfall seems to be comparable to earlier studies in the area (Lucas et al. 1993; Luizão et al. 2004; Wu et al. 2016), with slightly lower annual litter production. Possibly, the lower observed litterfall was a consequence of relatively higher litterfall in the preceding year, which had an El Niño event. Litterfall and forest productivity in general has been shown earlier to be strongly determined by precipitation and El Niño events (Hilker et al. 2014; Hofhansl et al. 2014); this is also in line with the relation between litter and precipitation we report. In other tropical forests, seasonality in litterfall has also been described, often attributed to a drier or a wetter season (Chave et al. 2010; Sayer and Tanner 2010; Parsons et al. 2014). Temperature can also drive leaf litterfall in other tropical systems (Kitayama et al. 2020), but at our site this relation was not as strong as the relation between precipitation and litter. Aboveground phenology and litterfall is well established to be seasonal in the tropics (Chave et al. 2010; Wu et al. 2017), and evidence is emerging that this is reflected in soil microbial communities (Buscardo et al. 2018).

\subsection{Substrate availability and enzyme activity}

Our study suggests that the soil extractable nutrient status might not always be related to EE's in the soil, partially confirming our fourth hypothesis. However, significant relations of eN with the enzyme activities 
suggests an importance of a supply of available $\mathrm{N}$ for microbial enzyme production, while the significant negative relation between AP and Olsen $\mathrm{P}$ signals a higher demand when the nutrient is in short supply. The observed negative relation between the enzyme C:N stoichiometry and the soil C:N ratio, together with the lack of a relation between NAG and litterfall, is indicative of a relative decoupling of nutrient availability and demand. Other studies point to the soil nutrient status as an important source of differences between EE activities (e.g., Olander and Vitousek 2000), which might still hold up if seasonality in the system is more visible in the quicker cycles, and to a lesser extent in more recalcitrant nutrient fractions. It is likely that our study shows a relative status quo where a) microbes (with possible contributions of AP root exudation) seem to be synchronized with seasonality by producing enzymes when the litter falls, b) available nutrients (measured here as eoC, eN and Olsen $\mathrm{P}$ ) in the mineral soil are taken up quickly (hours-days) by plants and microbes, therefore not clearly related to their corresponding enzyme (with an exception for $\mathrm{eN}$ ) and $\mathrm{c}$ ) the soil nutrients that are less available (represented partially by the total soil nutrient contents) follow a different pattern. However, if nutrients are cycling through the system at a rate that was not completely captured by our measurements; the enzyme activities might hold important cues about the timing of nutrient demand.

\subsection{Enzyme vectors and timing of microbial demand}

EE vector analysis, as conceptualized by Moorhead (2016), is increasingly used to distinguish between relative demand of $\mathrm{C}, \mathrm{N}$ and $\mathrm{P}$ acquiring enzymes. Although we do not use the exact same set of enzymes, we uncovered patterns that can be related to the phenology of soil microbial biomass and activity, related to the last hypothesis. Transforming the enzyme data to vectors of proportional activities indicated an increasing relative $\mathrm{N}$-demand in the months leading up to the drier season (lower vector angle) but saw this demand dropping during the drier season. During the drier season the P-enzymes were relatively more abundant (higher vector angle). Once leaf litter reaches the soil, there are different pathways to the inclusion in the soil as soil organic matter (SOM), where the labile components are released first, and particulate recalcitrant matter is incorporated in later stages (Cotrufo et al. 2013; Cotrufo et al. 2015). This time lag is a possible explanation for the vectors to show a relative trend towards more P-acquisition towards the end of the drier season; P-loss from litter is not immediate (Martins et al. 2021) and this might cause this delay in enzymatic response (Schaap et al. 2021). In both the drier and the wetter season, the vector angles are indicating a rather strong indication of P-limitation (Moorhead et al. 2016), especially at the lower depth. This is in line with a meta-analysis on enzymatic stoichiometry in the tropics (Waring et al. 2014). The vector lengths, indicating a relative shift towards Cacquisition (Moorhead et al. 2016), showed a less conclusive pattern, with a notable increase after the drier season in the 5-15 cm depth. Apart from the demand, this could also indicate higher availability of $C$ compounds (e.g., cellulose, hemicellulose) available from litter.

\section{Conclusion}

The aim of this study was to investigate seasonal soil nutrient dynamics through the interaction between litterfall, soil nutrients and EE. This study showed how leaf litterfall is connected to biochemical changes in the soil EE activity and stoichiometry. In line with our expectations the soil nutrients at the site are 
hinting towards a limitation of $\mathrm{P}$, which was further corroborated by a relatively high AP activity compared to $N A G$ and $B G$, indicating that the soils microbial community indeed had a high $P$ demand suggesting chronic $P$ limitation. Both BG and AP activities at the 5-15 cm depth were related to the leaf litter inputs, displaying a synchronization between nutrient inputs to the soil system and nutrient acquisition by $\mathrm{EE}$, which arguably points towards substrate availability as a driver for those EE activities, rather than (microbial) demand. The weaker relations found between enzymes and litter in the topsoil would suggest microbial demand is a more important driver there. Vectors of proportional enzyme activities uncovered a relative increase of $\mathrm{P}$ demand towards the end of the drier period and seem to indicate an increase of relative $\mathrm{N}$-demand in the months leading up to the drier season.

The study contributes to our understanding of the complex interactions in the dynamic tropical soil system. The study has observations from a single year, and future studies should address inter-annual variation in nutrient fluxes and the activity of the microbial biomass. Moreover, the study takes place in a single study area within the vastness of the tropical forest, warranting replication of the study in areas with different edaphic conditions and forest structure. Generally, greater efforts to understand effects of tropical seasonality on the fluxes of nutrients are needed to identify dependencies between components of the ecosystem. Studies of biochemical seasonality in soils remain relatively rare, even though they could be crucial in defining the response of nutritional cycles in tropical forests to gradual shifts in seasonality, such as a longer dry season. Information on tropical nutritional dynamics might prove critical when nutrient cycles are dependent on climate as they appear to be in this study; synchronization of seasonal patterns of nutrient inputs through litterfall and microbial activity are paramount through maintaining the nutrition of the tropical forest. This study identifies several dynamical interactions between seasonality, microbial activity and nutrient status of tropical soils that ought to be confirmed and expanded to better represent nutritional implications under future change scenarios.

\section{Declarations}

\section{Funding and acknowledgements}

We would like to acknowledge the AmazonFACE program of the National Institute of Amazonian Research (INPA), which was funded by the Inter-American Development Bank (IADB) through a technical cooperation agreement with the Brazilian Ministry of Science, Technology, Innovation and Communications (MCTI) Grant BR-T1284, by Brazil's Coordination for the Improvement of Higher Education Personnel (CAPES) Grant 23038.007722/2014-77 and Grant CAPES-

INPA/88881.154644/2017-01, and by Amazonas Research Foundation (FAPEAM) Grant 2649/2014. Additional funding was provided by the Brazilian National Council for Scientific and Technological Development (CNPq) Grant CNPq/LBA 68/2013. KS was supported by a CNPq/LBA 68/2013 PCl grant and by the AmazonFACE program with a CAPES scholarship Finance Code 001. LF was supported by the European Union's Horizon 2020 research and innovation program under the Marie Sklodovska-Curie grant agreement No 847693 (REWIRE). 
The authors thank Luciano Castilho for logistic support, Erison Gomes and Adriana Grandis for assistance with lab work and Alessandro Araújo and Mariana Gonçalves dos Reis for preparing and providing meteorological data. We are thankful to the AmazonFACE-team, the crew at the ZF2 field site, and the LTSP laboratory for general support.

\section{Competing Interests}

The authors have no relevant financial or non-financial interests to disclose.

\section{Data availability statement}

Data will be made available in a public repository upon publication

\section{Author Contributions}

KJS, MRH, LF, and CAQ conceptualized and designed the research. Experiments were carried out by KS and LF, with field support from FH and OVB. PBC's laboratory performed total $\mathrm{C}$ and $\mathrm{N}$ analyses. Statistical analyses were performed by KJS, with support from MRH, LF and FH. KJS prepared the manuscript, with contributions from LF, CAQ, FH, OVB and MRH.

\section{References}

1. Allen K, Fisher JB, Phillips RP, Powers JS, Brzostek ER (2020) Modeling the Carbon Cost of Plant Nitrogen and Phosphorus Uptake Across Temperate and Tropical Forests. Front For Glob Chang 3:112. https://doi.org/10.3389/ffgc. 2020.00043

2. Araújo AC, Nobre AD, Kruijt B, Elbers JA, Dallarosa R, Stefani P, Von Randow C, Manzi AO, Culf AD, Gash JHC, Valentini R, Kabat $P$ (2002) Comparative measurements of carbon dioxide fluxes from two nearby towers in a central Amazonian rainforest: The Manaus LBA site. J Geophys Res 107:120. https://doi.org/10.1029/2001JD000676

3. Bai X, Dippold MA, An S, Wang B, Zhang H, Loeppmann S (2021) Extracellular enzyme activity and stoichiometry: The effect of soil microbial element limitation during leaf litter decomposition. Ecol Indic 121:107200. https://doi.org/10.1016/j.ecolind.2020.107200

4. Baldrian $P$ (2009) Microbial enzyme-catalyzed processes in soils and their analysis. Plant, Soil Environ 55:370-378. https://doi.org/10.17221/134/2009-pse

5. Baldrian P, Šnajdr J, Merhautová V, Dobiášová P, Cajthaml T, Valášková V (2013) Responses of the extracellular enzyme activities in hardwood forest to soil temperature and seasonality and the potential effects of climate change. Soil Biol Biochem 56:60-68.

https://doi.org/10.1016/j.soilbio.2012.01.020

6. Bünemann EK (2015) Assessment of gross and net mineralization rates of soil organic phosphorus - A review. Soil Biol Biochem 89:82-98. https://doi.org/10.1016/j.soilbio.2015.06.026 
7. Burns RG (1982) Enzyme activity in soil: Location and a possible role in microbial ecology. Soil Biol Biochem 14:423-427. https://doi.org/10.1016/0038-0717(82)90099-2

8. Burns RG, DeForest JL, Marxsen J, Sinsabaugh RL, Stromberger ME, Wallenstein MD, Weintraub MN, Zoppini A (2013) Soil enzymes in a changing environment: Current knowledge and future directions. Soil Biol Biochem 58:216-234. https://doi.org/10.1016/j.soilbio.2012.11.009

9. Buscardo E, Geml J, Schmidt SK, Freitas H, Da Cunha HB, Nagy L (2018) Spatio-temporal dynamics of soil bacterial communities as a function of Amazon forest phenology. Sci Rep 8:1-13. https://doi.org/10.1038/s41598-018-22380-z

10. Cabugao KG, Yaffar D, Stenson N, Childs J, Phillips J, Mayes MA, Yang X, Weston DJ, Norby RJ (2021) Bringing function to structure: Root-soil interactions shaping phosphatase activity throughout a soil profile in Puerto Rico. Ecol Evol 11:1150-1164. https://doi.org/10.1002/ece3.7036

11. Camenzind T, Hättenschwiler S, Treseder KK, Lehmann A, Rillig MC (2018) Nutrient limitation of soil microbial processes in tropical forests. Ecol Monogr 88:4-21. https://doi.org/10.1002/ecm.1279

12. Cavicchioli R, Ripple WJ, Timmis KN, Azam F, Bakken LR, Baylis M, Behrenfeld MJ, Boetius A, Boyd PW, Classen AT, Crowther TW, Danovaro R, Foreman CM, Huisman J, Hutchins DA, Jansson JK, Karl DM, Koskella B, Mark Welch DB, Martiny JBH, Moran MA, Orphan VJ, Reay DS, Remais J V., Rich VI, Singh BK, Stein LY, Stewart FJ, Sullivan MB, van Oppen MJH, Weaver SC, Webb EA, Webster NS (2019) Scientists' warning to humanity: microorganisms and climate change. Nat Rev Microbiol 17:569-586. https://doi.org/10.1038/s41579-019-0222-5

13. Chave J, Navarrete D, Almeida S, Álvarez E, Aragão LEOC, Bonal D, Châtelet P, Silva-Espejo JE, Goret J-Y, von Hildebrand P, Jiménez E, Patiño S, Peñuela MC, Phillips OL, Stevenson P, Malhi Y (2010) Regional and seasonal patterns of litterfall in tropical South America. Biogeosciences 7:43-55. https://doi.org/10.5194/bg-7-43-2010

14. Cleveland CC, Townsend AR, Taylor P, Alvarez-Clare S, Bustamante MMC, Chuyong G, Dobrowski SZ, Grierson P, Harms KE, Houlton BZ, Marklein A, Parton W, Porder S, Reed SC, Sierra C a., Silver WL, Tanner EVJ, Wieder WR (2011) Relationships among net primary productivity, nutrients and climate in tropical rain forest: A pan-tropical analysis. Ecol Lett 14:939-947. https://doi.org/10.1111/j.14610248.2011.01658.x

15. Condit R, Engelbrecht BMJ, Pino D, Pérez R, Turner BL (2013) Species distributions in response to individual soil nutrients and seasonal drought across a community of tropical trees. Proc Natl Acad Sci U S A 110:5064-8. https://doi.org/10.1073/pnas.1218042110

16. Cordeiro AL, Norby RJ, Andersen KM, Valverde-Barrantes O, Fuchslueger L, Oblitas E, Hartley IP, Iversen CM, Gonçalves NB, Takeshi B, Lapola DM, Quesada CA (2020) Fine-root dynamics vary with soil depth and precipitation in a low-nutrient tropical forest in the Central Amazonia. PlantEnvironment Interact 1:3-16. https://doi.org/10.1002/pei3.10010

17. Cotrufo MF, Soong JL, Horton AJ, Campbell EE, Haddix ML, Wall DH, Parton WJ (2015) Formation of soil organic matter via biochemical and physical pathways of litter mass loss. Nat Geosci 8:776779. https://doi.org/10.1038/ngeo2520 
18. Cotrufo MF, Wallenstein MD, Boot CM, Denef K, Paul E (2013) The Microbial Efficiency-Matrix Stabilization (MEMS) framework integrates plant litter decomposition with soil organic matter stabilization: Do labile plant inputs form stable soil organic matter? Glob Chang Biol 19:988-995. https://doi.org/10.1111/gcb.12113

19. Cusack DF, Ashdown D, Dietterich LH, Neupane A, Ciochina M, Turner BL (2019) Seasonal changes in soil respiration linked to soil moisture and phosphorus availability along a tropical rainfall gradient. Biogeochemistry 145:235-254. https://doi.org/10.1007/s10533-019-00602-4

20. Dijkstra FA, Carrillo Y, Pendall E, Morgan JA (2013) Rhizosphere priming: A nutrient perspective. Front Microbiol 4:1-8. https://doi.org/10.3389/fmicb.2013.00216

21. Du E, Terrer C, Pellegrini AFA, Ahlström A, van Lissa CJ, Zhao X, Xia N, Wu X, Jackson RB (2020) Global patterns of terrestrial nitrogen and phosphorus limitation. Nat Geosci. https://doi.org/10.1038/s41561-019-0530-4

22. Eaton WD, McDonald S, Roed M, Vandecar KL, Hauge JB, Barry D (2011) A comparison of nutrient dynamics and microbial community characteristics across seasons and soil types in two different old growth forests in Costa Rica. Trop Ecol 52:35-48

23. García-Garrido JM, Ocampo JA, García-Romera I (2002) Enzymes in the arbuscular mycorrhizal symbiosis. In: Burns RG, Dick RP (eds) Enzymes in the Environment. Activity, Ecology and Applications. Marcel Dekker, Inc., New York, NY, USA, pp 125-151.

https://doi.org/10.1201/9780203904039

24. German DP, Weintraub MN, Grandy a. S, Lauber CL, Rinkes ZL, Allison SD (2011) Optimization of hydrolytic and oxidative enzyme methods for ecosystem studies. Soil Biol Biochem 43:1387-1397. https://doi.org/10.1016/j.soilbio.2011.03.017

25. Hilker T, Lyapustin Al, Tucker CJ, Hall FG, Myneni RB, Wang Y, Bi J, Mendes de Moura Y, Sellers PJ (2014) Vegetation dynamics and rainfall sensitivity of the Amazon. Proc Natl Acad Sci 111:1604116046. https://doi.org/10.1073/pnas. 1404870111

26. Hofhansl F, Kobler J, Ofner J, Drage S, Pölz E, Wanek W (2014) Sensitivity of tropical forest aboveground productivity to climate anomalies in SW Costa Rica. Global Biogeochem Cycles 28:1437-1454. https://doi.org/10.1002/2014GB004934

27. Hou E, Luo Y, Kuang Y, Chen C, Lu X, Jiang L, Luo X, Wen D (2020) Global meta-analysis shows pervasive phosphorus limitation of aboveground plant production in natural terrestrial ecosystems. Nat Commun 11:1-9. https://doi.org/10.1038/s41467-020-14492-w

28. Isles PDF (2020) The misuse of ratios in ecological stoichiometry. Ecology. https://doi.org/10.1002/ecy.3153

29. Kitayama K, Ushio M, Aiba S (2020) Temperature is a dominant driver of distinct annual seasonality of leaf litter production of equatorial tropical rain forests. J Ecol 1365-2745.13500. https://doi.org/10.1111/1365-2745.13500

30. Lucas Y, Luizão FJ, Chauvel A, Rouiller J, Nahon D (1993) The Relation Between Biological Activity of the Rain Forest and Mineral Composition of Soils. Science (80-) 260:521-523. 
https://doi.org/10.1126/science.260.5107.521

31. Lugli LF, Andersen KM, Aragão LEOCOC, Cordeiro AL, Cunha HF V., Fuchslueger L, Meir P, Mercado LM, Oblitas E, Quesada CA, Rosa JS, Schaap KJ, Valverde-Barrantes O, Hartley IP (2020) Multiple phosphorus acquisition strategies adopted by fine roots in low-fertility soils in Central Amazonia. Plant Soil 450:49-63. https://doi.org/10.1007/s11104-019-03963-9

32. Luizão RCC, Luizão FJ, Paiva RQ, Monteiro TF, Sousa LSLS, Kruijt B (2004) Variation of carbon and nitrogen cycling processes along a topographic gradient in a central Amazonian forest. Glob Chang Biol 10:592-600. https://doi.org/10.1111/j.1529-8817.2003.00757.x

33. Luo L, Meng H, Gu J-D (2017) Microbial extracellular enzymes in biogeochemical cycling of ecosystems. J Environ Manage 197:539-549. https://doi.org/10.1016/j.jenvman.2017.04.023

34. Martins NP, Fuchslueger L, Fleischer K, Andersen KM, Assis RL, Baccaro FB, Camargo PB, Cordeiro AL, Grandis A, Hartley IP, HofhansI F, Lugli LF, Lapola DM, Menezes JG, Norby RJ, Rammig A, Rosa JS, Schaap KJ, Takeshi B, Valverde-Barrantes OJ, Quesada CA (2021) Fine roots stimulate nutrient release during early stages of leaf litter decomposition in a Central Amazon rainforest. Plant Soil. https://doi.org/10.1007/s11104-021-05148-9

35. Marx MC, Wood M, Jarvis SC (2001) A microplate fluorimetric assay for the study of enzyme diversity in soils. Soil Biol Biochem 33:1633-1640. https://doi.org/10.1016/S0038-0717(01)00079-7

36. Moorhead DL, Sinsabaugh RL, Hill BH, Weintraub MN (2016) Vector analysis of ecoenzyme activities reveal constraints on coupled C, N and P dynamics. Soil Biol Biochem 93:1-7. https://doi.org/10.1016/j.soilbio.2015.10.019

37. Murphy J, Riley JP (1962) A modified single solution method for the determination of phosphate in natural waters. Anal Chim Acta 27:31-36. https://doi.org/10.1016/S0003-2670(00)88444-5

38. Nasto MK, Alvarez-Clare S, Lekberg Y, Sullivan BW, Townsend AR, Cleveland CC (2014) Interactions among nitrogen fixation and soil phosphorus acquisition strategies in lowland tropical rain forests. Ecol Lett 17:1282-1289. https://doi.org/10.1111/ele.12335

39. Nottingham AT, Turner BL, Whitaker J, Ostle N, Bardgett RD, McNamara NP, Salinas N, Meir P (2016) Temperature sensitivity of soil enzymes along an elevation gradient in the Peruvian Andes. Biogeochemistry 127:217-230. https://doi.org/10.1007/s10533-015-0176-2

40. Olander LP, Vitousek PM (2000) Regulation of soil phosphatase and chitinase activity by $\mathrm{N}$ and $\mathrm{P}$ availability. Biogeochemistry 49:175-190. https://doi.org/10.1023/A:1006316117817

41. Olsen SR, Cole C V., Watanabe FS, Dean LA (1954) Estimation of available phosphorus in soils by extraction with sodium bicarbonate. United States Dep Agric Circ 939:1-19

42. Pajares S, Campo J, Bohannan BJM, Etchevers JD (2018) Environmental Controls on Soil Microbial Communities in a Seasonally Dry Tropical Forest. Appl Environ Microbiol 84:1-19. https://doi.org/10.1128/AEM.00342-18

43. Parsons SA, Valdez-Ramirez V, Congdon RA, Williams SE (2014) Contrasting patterns of litterfall seasonality and seasonal changes in litter decomposability in a tropical rainforest region. Biogeosciences 11:5047-5056. https://doi.org/10.5194/bg-11-5047-2014 
44. Pereira IS, do Nascimento HEM, Vicari MB, Disney M, DeLucia EH, Domingues T, Kruijt B, Lapola D, Meir P, Norby RJ, Ometto JPHB, Quesada CA, Rammig A, HofhansI F (2019) Performance of laserbased electronic devices for structural analysis of Amazonian terra-firme forests. Remote Sens 11:. https://doi.org/10.3390/rs11050510

45. Quesada B, Vautard R, Yiou P, Hirschi M, Seneviratne SI (2012) Asymmetric European summer heat predictability from wet and dry southern winters and springs. Nat Clim Chang 2:736-741. https://doi.org/10.1038/nclimate1536

46. Quesada CA, Lloyd J, Schwarz M, Patiño S, Baker TR, Czimczik C, Fyllas NM, Martinelli L, Nardoto GB, Schmerler J, Santos a. JB, Hodnett MG, Herrera R, Luizão FJ, Arneth A, Lloyd G, Dezzeo N, Hilke I, Kuhlmann I, Raessler M, Brand W a., Geilmann H, Filho JOM, Carvalho FP, Filho RNA, Chaves JE, Cruz OF, Pimentel TP, Paiva R (2010) Variations in chemical and physical properties of Amazon forest soils in relation to their genesis. Biogeosciences 7:1515-1541. https://doi.org/10.5194/bg-7-15152010

47. R Core Team (2020) R: A Language and Environment for Statistical Computing, 3.4.0. R Foundation for Statistical Computing, Vienna, Austria. https://www.r-project.org/

48. Restrepo-Coupe N, Levine NM, Christoffersen BO, Albert LP, Wu J, Costa MH, Galbraith D, Imbuzeiro H, Martins G, da Araujo AC, Malhi YS, Zeng X, Moorcroft P, Saleska SR (2016) Do dynamic global vegetation models capture the seasonality of carbon fluxes in the Amazon basin? A data-model intercomparison. Glob Chang Biol. https://doi.org/10.1111/gcb.13442

49. Ruan HH, Zou XM, Scatena FN, Zimmerman JK (2004) Asynchronous fluctuation of soil microbial biomass and plant litterfall in a tropical wet forest. Plant Soil 260:147-154.

https://doi.org/10.1023/B:PLS0.0000030177.20951.94

50. Sanches L, Valentini CMA, Pinto Júnior OB, Nogueira J de S, Vourlitis GL, Biudes MS, da Silva CJ, Bambi P, Lobo F de A (2008) Seasonal and interannual litter dynamics of a tropical semideciduous forest of the southern Amazon Basin, Brazil. J Geophys Res Biogeosciences 113:1-9. https://doi.org/10.1029/2007JG000593

51. Sayer EJ, Tanner EVJ (2010) Experimental investigation of the importance of litterfall in lowland semi-evergreen tropical forest nutrient cycling. J Ecol 98:1052-1062. https://doi.org/10.1111/j.13652745.2010.01680.x

52. Schaap KJ, Fuchslueger L, Hoosbeek MR, Hofhansl F, Martins NP, Valverde-Barrantes OJ, Hartley IP, Lugli LF, Quesada CA (2021) Litter inputs and phosphatase activity affect the temporal variability of organic phosphorus in a tropical forest soil in the Central Amazon. Plant Soil 469:423-441. https://doi.org/10.1007/s11104-021-05146-x

53. Sinsabaugh RL, Follstad Shah JJ (2012) Ecoenzymatic Stoichiometry and Ecological Theory. Annu Rev Ecol Evol Syst 43:120913143848009. https://doi.org/10.1146/annurev-ecolsys-071112-124414

54. Sinsabaugh RL, Lauber CL, Weintraub MN, Ahmed B, Allison SD, Crenshaw C, Contosta AR, Cusack D, Frey S, Gallo ME, Gartner TB, Hobbie SE, Holland K, Keeler BL, Powers JS, Stursova M, Takacs- 
Vesbach C, Waldrop MP, Wallenstein MD, Zak DR, Zeglin LH (2008) Stoichiometry of soil enzyme activity at global scale. Ecol Lett 11:1252-1264. https://doi.org/10.1111/j.1461-0248.2008.01245.x

55. Skujiņš J, Burns RG (1976) Extracellular enzymes in soil. Crit Rev Microbiol 4:383-421. https://doi.org/10.3109/10408417609102304

56. Soong JL, Fuchslueger L, Marañon-Jimenez S, Torn MS, Janssens IA, Penuelas J, Richter A (2020) Microbial carbon limitation: The need for integrating microorganisms into our understanding of ecosystem carbon cycling. Glob Chang Biol 26:1953-1961. https://doi.org/10.1111/gcb.14962

57. Tischer A, Blagodatskaya E, Hamer U (2014) Extracellular enzyme activities in a tropical mountain rainforest region of southern Ecuador affected by low soil $\mathrm{P}$ status and land-use change. Appl Soil Ecol 74:1-11. https://doi.org/10.1016/j.apsoil.2013.09.007

58. Vitousek PM (1984) Litterfall, Nutrient Cycling, and Nutrient Limitation in Tropical Forests. Ecology 65:285. https://doi.org/10.2307/1939481

59. Vitousek PMM, Porder S, Houlton BZZ, Oliver A, Vitousek PMM, Porder S, Houlton BZZ, Chadwick O a A, Oliver A, Vitousek PMM, Porder S, Houlton BZZ, Chadwick O a A (2010) Terrestrial phosphorus limitation: mechanisms, implications, and nitrogen - phosphorus interactions. Ecol Appl 20:5-15. https://doi.org/10.1890/08-0127.1

60. Walker TW, Syers JK (1976) The fate of phosphorus during pedogenesis. Geoderma 15:1-19. https://doi.org/10.1016/0016-7061(76)90066-5

61. Waring BG, Weintraub SR, Sinsabaugh RL (2014) Ecoenzymatic stoichiometry of microbial nutrient acquisition in tropical soils. Biogeochemistry 117:101-113. https://doi.org/10.1007/s10533-0139849-X

62. Weintraub SR, Wieder WR, Cleveland CC, Townsend AR (2013) Organic matter inputs shift soil enzyme activity and allocation patterns in a wet tropical forest. Biogeochemistry 114:313-326. https://doi.org/10.1007/s10533-012-9812-2

63. Wieder RK, Wright SJ (1995) Tropical Forest Litter Dynamics and Dry Season Irrigation on Barro Colorado Island, Panama. Ecology 76:1971-1979. https://doi.org/10.2307/1940727

64. Wu J, Albert LP, Lopes AP, Restrepo-Coupe N, Hayek M, Wiedemann KT, Guan K, Stark SC, Christoffersen B, Prohaska N, Tavares J V, Marostica S, Kobayashi H, Ferreira ML, Campos KS, da Silva R, Brando PM, Dye DG, Huxman TE, Huete AR, Nelson BW, Saleska SR (2016) Leaf development and demography explain photosynthetic seasonality in Amazon evergreen forests. Science (80-) 351:972-976. https://doi.org/10.1126/science.aad5068

65. Wu J, Serbin SP, Xu X, Albert LP, Chen M, Meng R, Saleska SR, Rogers A (2017) The phenology of leaf quality and its within-canopy variation are essential for accurate modeling of photosynthesis in tropical evergreen forests. Glob Chang Biol 38:42-49. https://doi.org/10.1111/gcb.13725

66. Yamashita N, Ohta S, Sase H, Luangjame J, Visaratana T, Kievuttinon B, Garivait H, Kanzaki M (2010) Seasonal and spatial variation of nitrogen dynamics in the litter and surface soil layers on a tropical dry evergreen forest slope. For Ecol Manage 259:1502-1512. https://doi.org/10.1016/j.foreco.2010.01.026 
67. Yang LH, Edwards KF, Byrnes JE, Bastow JL, Wright AN, Spence KO (2010) A meta-analysis of resource pulse-consumer interactions. Ecol Monogr 80:125-151. https://doi.org/10.1890/08-1996.1

68. Zeglin LH, Kluber LA, Myrold DD (2013) The importance of amino sugar turnover to $C$ and $N$ cycling in organic horizons of old-growth Douglas-fir forest soils colonized by ectomycorrhizal mats. Biogeochemistry 112:679-693. https:// doi.org/10.1007/s10533-012-9746-8

69. Zuccarini P, Asensio D, Ogaya R, Sardans J, Peñuelas J (2020) Effects of seasonal and decadal warming on soil enzymatic activity in a P-deficient Mediterranean shrubland. Glob Chang Biol 26:3698-3714. https://doi.org/10.1111/gcb.15077

\section{Figures}
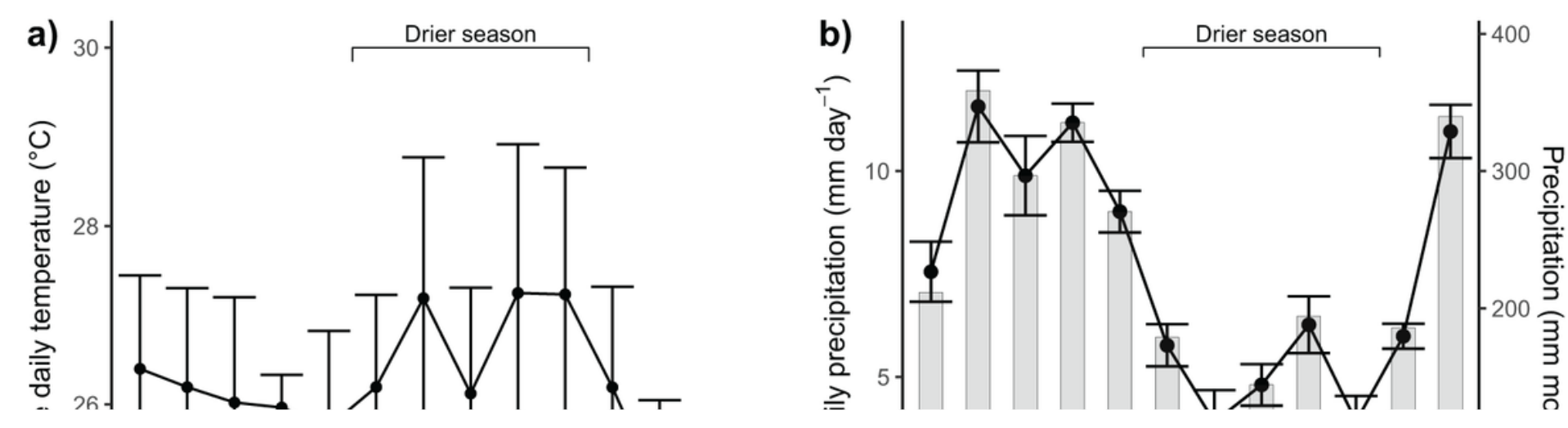

\section{Figure 1}

a) daily average air temperature (at $34.6 \mathrm{~m}$, above forest canopy), and b) rainfall at the AmazonFACE plots, daily average (line and dots \pm SE) and the monthly sum (bars). Both temperature and precipitation were measured every 30 minutes and calculated per day ( $n=48$ per day). The "Dry season" bracket indicates which months are treated as the drier months of the year in the rest of the manuscript, defined as the months with less than $40 \%$ of days with $<3 \mathrm{~mm}$ precipitation. 

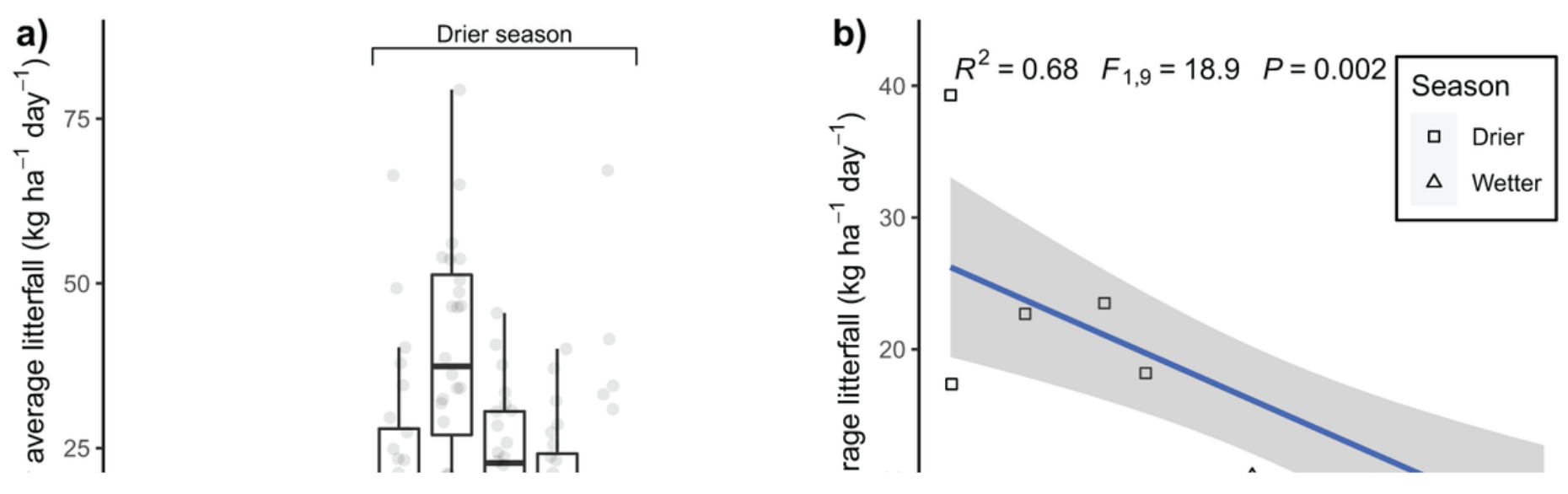

\section{Figure 2}

a) leaf litter collected (biweekly) at the AmazonFACE plots, recalculated for an average daily litter quantity per trap (each observation represents a different trap, $n=24$. Boxplot shows median and quartiles), and b) the relation between average daily leaf litterfall and average daily precipitation per month. Dry season indicates the dry months as established in Fig. 1.

\section{Figure 3}

C, $\mathrm{N}$ and P related extracellular enzyme activities (BG, NAG and AP per soil C) from February 2016 till January 2017, and their relation to the average monthly leaf litterfall. Boxplots are showing the median, the lower and upper hinges correspond to the first and third quartiles

\section{Figure 4}

Relations between EES and soil nutrient stoichiometry, and enzyme activities as related to each other, at 0-5 $\mathrm{cm}$ and $5-15 \mathrm{~cm}$. a) relation between $\mathrm{C}: \mathrm{N}$ ratios of soil nutrients and enzymes, b) relation between $\mathrm{C}$ and $N$ enzyme activities (BG and NAG), c) relation between C:P ratios of soil nutrients and enzymes, $d$ ) relation between $C$ and $P$ enzyme activities (BG and $A P), e$ ) relation between N:P ratios of soil nutrients and enzymes, $d$ ) relation between $N$ and $P$ enzyme activities (NAG and AP). 


\section{Figure 5}

Average monthly vectors of proportional enzyme activities at a) $0-5 \mathrm{~cm}$ and b) $5-15 \mathrm{~cm}$, and average vector properties $\mathrm{c}$ ) length (unitless), and d) angle (in degrees) of the monthly average vectors. Vectors above the 1:1 line in a) and b) are P-limited according to the vectors, below the line are considered $\mathrm{N}$ limited. The error bar in c) and d) represents the standard error).

\section{Supplementary Files}

This is a list of supplementary files associated with this preprint. Click to download.

- Manuscript220supplementarymaterial.docx 